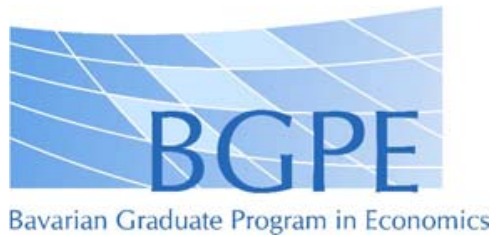

BGPE Discussion Paper

No. 9

\title{
Financial Incentives and the Timing of Retirement: Evidence from Switzerland
}

\author{
Barbara Hanel \\ Regina T. Riphahn
}

December 2006

ISSN 1863-5733

Editor: Prof. Regina T. Riphahn, Ph.D.

Friedrich-Alexander-University Erlangen-Nuremberg

(c) Barbara Hanel, Regina T. Riphahn 


\title{
Financial Incentives and the Timing of Retirement: Evidence from Switzerland
}

\author{
Barbara Hanel \\ and \\ Regina T. Riphahn
}

December 5, 2006

\begin{abstract}
We use reforms in the Swiss public retirement system to identify the responsiveness of retirement timing to financial incentives. A permanent reduction of retirement benefits by 3.4 percent induces more than 70 percent of females to postpone their retirement. The responsiveness of male workers, who undergo a different treatment, is lower.
\end{abstract}

Keywords: $\quad$ retirement insurance, incentives, social security, labor force exit, JEL Keywords: $\quad$ J26, H55, J14

Correspondence to:

Regina T. Riphahn

Department of Economics

University of Erlangen-Nuremberg

Lange Gasse 20

90403 Nuremberg

Germany

Phone: +49-911-5302 826

Fax: $\quad+49-911-5302178$

Email: regina.riphahn@wiso.uni-erlangen.de 


\section{Introduction and Background}

Under pressure to prepare for imminent population aging, the retirement insurances of many industrialized countries consider reforms that set incentives to postpone retirement. A large literature attempts to quantify the effect of such retirement incentives, and the problems connected to identifying causal effects and to representing retirement incentives are widely discussed (Lumsdaine and Mitchell 1999, Coile and Gruber 2000, or Chan and Huff Stevens 2004). We provide evidence from a recent natural experiment in Switzerland in the spirit of Krueger and Pischke (1992).

The Swiss retirement system (for a description see Bütler 2002) consists of a public social security pillar (AHV), financed mainly by payroll taxes, and of heterogeneous private pension systems as a second pillar. The public AHV pillar sets a minimum age as an eligibility criterion for benefit receipt. For men this age has always been fixed at 65, while females were able to retire at age 62. In 1991 a reform law ("10th revision") passed, which prompted two types of changes that we use as a natural experiment in our analysis.

First, the minimum age for women's full retirement benefit eligibility was ratcheted up in two steps from 62 years up to 64 years, while the minimum age for men remained at 65 years. Second, it became possible for women and men to retire prior to that minimum age. The option to draw retirement benefits one year (and in a second step two years) prior to the minimum retirement age was introduced at the price of a permanent benefit discount. Since women already suffered the disadvantage of postponed regular retirement, their benefit reduction was half that of men. Table 1 reports the timing of the reform's implementation as well as the benefit reductions tied to early retirement. ${ }^{1}$

Based on these reforms we expect two responses: (a) the retirement propensity of 62 and 63 year old women should decline when regular retirement age increases and benefit reductions are implemented for early retirement. (b) Men should start taking up retirement

\footnotetext{
${ }^{1}$ Workers can also postpone receiving their benefits for up to five years. Since 1991 this yields a maximum increase in benefits of 31.5 percent (BSV 2006).
} 
benefits prior to age 65 when the option of early retirement is introduced. Clearly, making a given practice costly (for women) and expanding retirement opportunities (for men) are distinct events that may call forth distinct responses. We investigate the behavioral responsiveness to these incentives.

\section{Data and Approach}

Our data are taken from the Swiss Labor Force Survey (1991-2005), which is a rotating panel with up to five interviews per person and covers a representative sample of the Swiss population. In our estimations we consider all individuals aged 60 through 70 who were either employed or unemployed members of the labor force. This provides us with 8,083 and 5,910 person-year observations for 4,067 different males and 3,222 different females. Of the observed males and females 34.6 and 40.5 percent make a transition to retirement, constituting 17.4 and 22.1 percent of the person-year observations. We censor observations after retirement.

The dependent variable describes whether a member of the labor force in year $\mathrm{t}$ indicates to be retired in year $\mathrm{t}+1$. Unfortunately the data does not inform on the self declared retirees' income sources. Some of our retirees may not be receiving benefits from the first pillar of the retirement insurance when they indicate retirement. For our purposes this causes measurement error in the dependent variable increasing the standard errors of our estimates. Figure 1 depicts the retirement probabilities by age over time: women's propensity to retire at age 62 clearly declined when the first reform materialized in 2001 and again in 2005 when benefits were reduced further. Instead, the probability of retirement at age 63 went up after 2001 and came down again when regular retirement age increased to age 64 . The spike in the retirement propensity at age 64 in 2002 and 2003 is spurious and related to an extremely small number of observations. Male retirement entry shows no clear response to the modified regulations which allowed retirement at age 64 starting in 1997 and at 63 starting in 2001. 
Our estimation applies a difference-in-differences approach, where we control for individual age and the year of observation. We add indicators for the groups which are affected by the institutionally modified retirement incentives: the propensity to retire should decline for 62 year old females after 2000 and again after 2004, and similarly for 63 year old women after 2004. For men we expect increasing inflows into retirement for the 64 (63) year olds after 1996 (2000).

We use a discrete time hazard model to test whether the institutional changes in retirement regulations yielded statistically significant behavioral responses. We apply random effects logit estimators to control for person-specific correlations in standard errors. Besides age, year, and incentive effects we consider individual characteristics such as education, marital status, and the industry of a last or current employment in our specifications.

\section{Results and Discussion}

The estimation results are presented in Table 2 separately for females and males. Columns 1 through 3 subsequently add control variables to the model specification. The coefficients of the incentive effects for women and men are presented in Panels A and C, respectively. These coefficient estimates are highly statistically significant for the female sample. For women the predicted retirement propensities (see Panel B) changed substantially and significantly when financial incentives were modified: the probability to retire at age 62 fell by 70 percent between 2000 and 2001, when the regular retirement age was shifted and retirement at age 62 became available at the price of 3.4 percent of total benefits. While the benefit reductions for the 2005 reforms also amounted to 3.4 percent, the response rates where somewhat smaller: the propensity to retire at age 62 fell by an additional 45 percent between 2004 and 2005, and the propensity to retire at age 63 fell by about 34 percent when the benefit reductions were introduced in 2005. All of these changes are statistically 
significant and suggest that the older female labor force was quite responsive to shifts in retirement incentives.

The estimated responses of male workers are much more modest. The incentive variables here do not yield statistically significant coefficient estimates (see Panel C), even though the predicted effects indicate substantial and significant behavioral adjustments in the expected directions (see Panel D): when early retirement options became first available in 1997, the propensity to seek retirement at age 64 increased by over 50 percent based on the results in columns 2 and 3. The retirement propensity at age 63 increased by about 33 percent in 2001, conditional on personal characteristics. ${ }^{2}$

In separate estimations (not presented to save space) we tested whether the response to the regulatory reforms changed over time. The results indicate that indeed both men and women increasingly responded to the reforms and adjusted their behaviors more strongly as time went by under new regulations. Given that the information on changes in retirement incentives had been available since 1991 and had been publicized through a referendum on the issue in 1995 (Bütler 2002), this supports the existence of a social "retirement norm" or "focal point", which takes time to adjust.

Overall these findings confirm prior studies (e.g. Asch et al. 2005) and suggest that reforms in financial retirement incentives may still be able to substantially affect the retirement plans of the generations to come.

\footnotetext{
${ }^{2}$ All results are robust to applying a linear probability model instead of a logit estimator.
} 


\section{Bibliography}

Asch, B., S.J. Haider, and J. Zissimopoulos, 2005, Financial Incentives and Retirement: Evidence from Federal Civil Service Workers, Journal of Public Economics 89(2-3), 427440.

BSV (Bundesamt für Sozialversicherungen), 2006, Statistiken zur sozialen Sicherheit: AHV Statistik 2006, Bern / Switzerland.

Bütler, M. 2002, The Political Feasibility of Increasing the Retirement Age: Lessons from a Ballot on the Female Retirement Age, International Tax and Public Finance 9, 345-365.

Chan, S. and A. Huff Stevens, 2004, Do changes in pension incentives affect retirement? A Longitudinal Study of Subjective Retirement Expectations, Journal of Public Economics 88 (7-8), 1307-1333.

Coile, C. and J. Gruber, 2000, Social Security and Retirement, NBER Working Paper No. 7830, Cambridge.

Krueger, A. and J.S. Pischke, 1992, The Effect of Social Security on Labor Supply: A Cohort Analysis of the Notch Generation, Journal of Labor Economics 10(4), 412-437.

Lumsdaine, R. and O. Mitchell, 1999, New Developments in the Economic Analysis of Retirement, in: Ashenfelter, O. and D. Card, eds., Handbook of Labor Economics Vol. 3C, (North Holland, Amsterdam) 3261-3307.

Table 1: Regular Retirement Age and Early Retirement Options after the 1991 Reform

\begin{tabular}{l|ccc|ccc}
\cline { 2 - 6 } & \multicolumn{3}{c|}{ Men } & \multicolumn{3}{c}{ Women } \\
\cline { 2 - 7 } & $\begin{array}{c}\text { Regular Retirement } \\
\text { Age }\end{array}$ & \multicolumn{2}{c|}{$\begin{array}{c}\text { Early Retirement Age } \\
\text { (\% Benefit Reduction) }\end{array}$} & $\begin{array}{c}\text { Regular Retirement } \\
\text { Age }\end{array}$ & $\begin{array}{c}\text { Early Retirement Age } \\
\text { (\% Benefit Reduction) }\end{array}$ \\
\hline 1996 & 65 & - & - & 62 & - & - \\
$1997-2000$ & 65 & $64(6.8 \%)$ & - & 62 & - & - \\
$2001-2004$ & 65 & $64(6.8 \%)$ & $63(13.6 \%)$ & 63 & $62(3.4 \%)$ & - \\
starting 2005 & 65 & $64(6.8 \%)$ & $63(13.6 \%)$ & 64 & $63(3.4 \%)$ & $62(6.8 \%)$ \\
\hline
\end{tabular}


Table 2: Random Effects Logit Estimation: Results for the Probability to Retire

\begin{tabular}{|c|c|c|c|}
\hline & $\begin{array}{r}\text { Coeff. } \\
\text { (t-value) } \\
(1) \\
\end{array}$ & $\begin{array}{r}\text { Coeff. } \\
\text { (t-value) } \\
(2) \\
\end{array}$ & $\begin{array}{r}\text { Coeff. } \\
\text { (t-value) } \\
(3) \\
\end{array}$ \\
\hline \multicolumn{4}{|c|}{ A - Women: Estimation results } \\
\hline Incentive: age 62 after 2000 & $\begin{array}{l}-1.891 * * \\
(-8.08)\end{array}$ & $\begin{array}{l}-1.913 * * \\
(-8.16)\end{array}$ & $\begin{array}{l}-1.916 * * \\
(-8.15)\end{array}$ \\
\hline Incentive: age 62 after 2004 & $\begin{array}{l}-2.513 * * \\
(-7.10)\end{array}$ & $\begin{array}{l}-2.556 * * \\
(-7.19)\end{array}$ & $\begin{array}{l}-2.563 * * \\
(-7.19)\end{array}$ \\
\hline Incentive: age 63 after 2004 & $\begin{array}{l}-0.542 \\
(-1.79)\end{array}$ & $\begin{array}{l}-0.603 * \\
(-1.98)\end{array}$ & $\begin{array}{l}-0.661 * \\
(-2.16)\end{array}$ \\
\hline Age (10) & yes $* *$ & yes $* *$ & yes $* *$ \\
\hline Year (13) & yes $* *$ & yes ** & yes ** \\
\hline Education (5) & - & yes $* *$ & yes $* *$ \\
\hline Marital status (4) & - & yes & yes \\
\hline Industry (11) & - & - & yes ** \\
\hline \multicolumn{4}{|c|}{ B - Women: Predicted retirement probability } \\
\hline \multirow{2}{*}{$\begin{array}{l}\text { Age } 622000 \\
\text { Age } 622001\end{array}$} & $25.56 * *$ & \multirow{2}{*}{$\begin{array}{r}26.65 \\
7.89\end{array}$} & \multirow{2}{*}{$\begin{array}{r}26.55 \\
7.95\end{array}$} \\
\hline & 7.43 & & \\
\hline \multirow{2}{*}{$\begin{array}{l}\text { Age } 622004 \\
\text { Age } 622005\end{array}$} & $9.10_{* *}$ & \multirow{2}{*}{$\begin{array}{l}9.92 \\
5.36\end{array}$} & \multirow{2}{*}{$\begin{array}{c}10.00 \\
5.51\end{array} *$} \\
\hline & 4.90 & & \\
\hline \multirow{2}{*}{$\begin{array}{l}\text { Age } 632004 \\
\text { Age } 632005 \\
\end{array}$} & $36.63 *$ & \multirow{2}{*}{$\begin{array}{l}38.87 \\
25.58\end{array} * *$} & \multirow{2}{*}{$\begin{array}{l}39.01 \\
25.15\end{array}$} \\
\hline & 24.38 & & \\
\hline \multicolumn{4}{|l|}{ C - Men: Estimation results } \\
\hline Incentive: age 64 after 1996 & $\begin{array}{r}-0.002 \\
(-0.007)\end{array}$ & $\begin{array}{l}-0.032 \\
(-0.12)\end{array}$ & $\begin{array}{l}-0.061 \\
(-0.22)\end{array}$ \\
\hline Incentive: age 63 after 2000 & $\begin{array}{r}0.279 \\
(1.17)\end{array}$ & $\begin{array}{r}0.258 \\
(1.08)\end{array}$ & $\begin{array}{r}0.264 \\
(1.09)\end{array}$ \\
\hline Age (10) & yes $* *$ & yes $* *$ & yes ** \\
\hline Year (13) & yes & yes & yes \\
\hline Education (5) & - & yes $* *$ & yes $* *$ \\
\hline Marital status (4) & - & yes & yes \\
\hline Industry (11) & - & - & yes ** \\
\hline \multicolumn{4}{|c|}{ D - Men: Predicted retirement proability } \\
\hline Age 641996 & 8.53 & $7.14 *$ & $7.18 *$ \\
\hline Age 641997 & 10.38 & 10.96 & $11.37^{*}$ \\
\hline Age 632000 & 6.640 & $7.10_{0}$ & 7.17 \\
\hline Age 632001 & 9.030 & 9.380 & 9.55 \\
\hline
\end{tabular}

Note: $* *, *$ and ${ }^{0}$ indicate statistical significance at the 1,5 , and 10 percent level. The estimations for females use 5,910 those for males 8,083 person-year observations. The numbers in parentheses in the very first column indicate the number of coefficients estimated in each group of covariates. In all cases a LM test rejected the hypothesis that individual specific random effects had a variance of zero. In panels $\mathrm{B}$ and $\mathrm{D}$ the asterisks indicate the statistical significance of the difference between the predicted probabilities. Here the standard errors were bootstrapped with 300 draws from the original sample. 
Figure 1: Probability of a Transition to Retirement by Age over Time

\section{(a) Females}

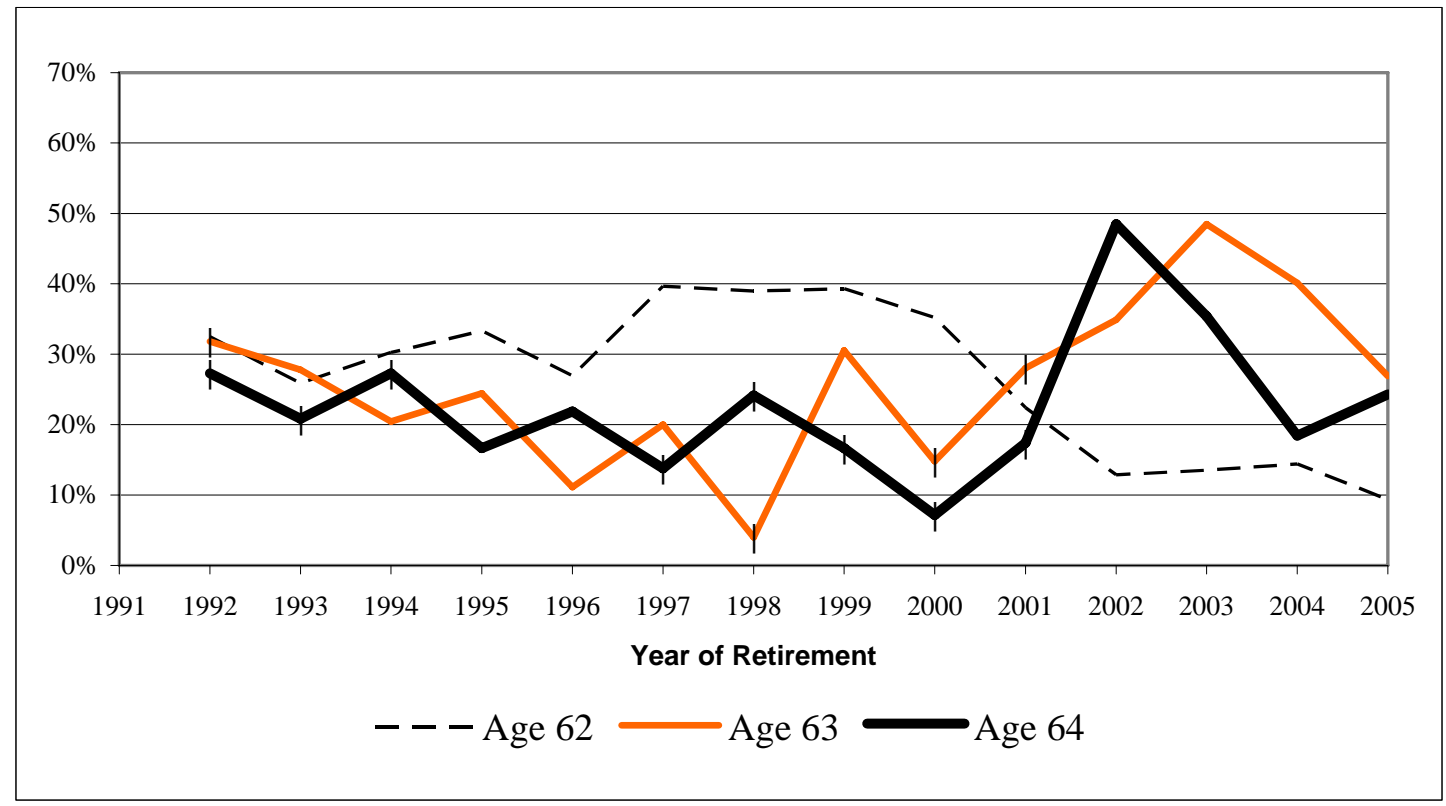

(b) Males

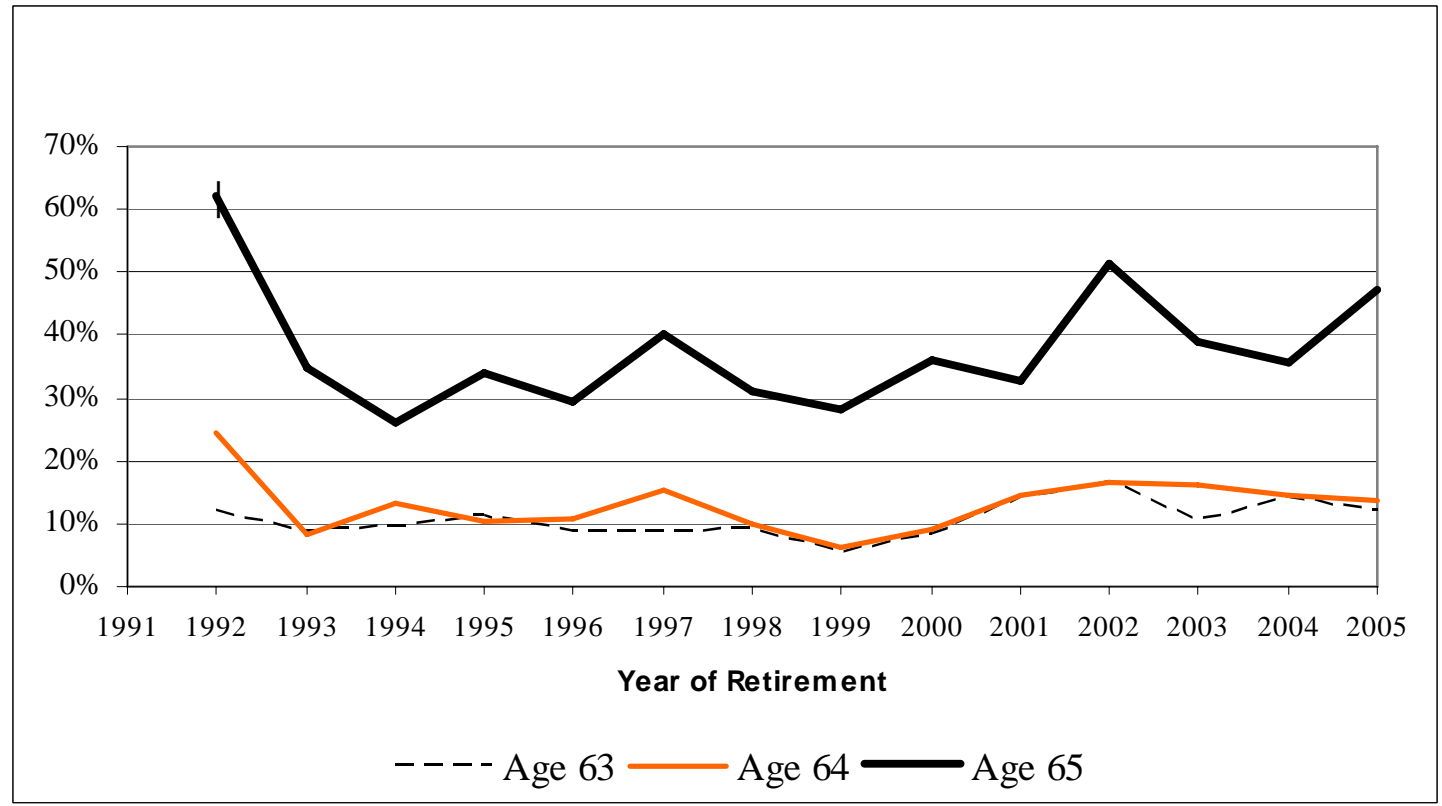

Source: Own calculations based on Swiss Labor Force Survey (1991-2005).

Note: Vertical dashes indicate calculations based upon less than 30 observations. 